\title{
In Vitro Culture of the Anxiolytic Plant, Souroubea Sympetala
}

\author{
Alejandra Rojas Vargas, $\mathrm{MSc}^{1 *}$, Ana Hine Gómez, $\mathrm{MSc}^{1}$, Rui Liu, $\mathrm{PHD}^{2}$, Marco Otarola-Rojas, $\mathrm{MSc}^{3}$, \\ Pablo Sanchez Vindas, $\mathrm{MSc}^{3}$, Tony Durst, $\mathrm{PHD}^{2}$, John T. Arnason, $\mathrm{PHD}^{4 *}$ \\ ${ }^{1}$ Instituto de Investigacion de Servicios Forestales (INISEFOR), Universidad Nacional Autonoma, Heredia 3000, Costa Rica \\ ${ }^{2}$ Department of Biology, 30 Marie Curie, University of Ottawa, Ottawa ON K1N 6N5 \\ ${ }^{3}$ Herbario JVR, Universidad Nacional Autonoma, Heredia 3000, Costa Rica Marco \\ ${ }^{4}$ Department of Chemistry and Molecular Sciences, 10 Marie Curie, University of Ottawa, Ottawa ON K1N 6N5 \\ *@ Corresponding Authors: john.arnason@uottawa.ca and alejandra.rojas.vargas@una.cr
}

\begin{abstract}
INTRODUCTION: A protocol for the in vitro culture of the anxiolytic medicinal plant Souroubea sympetala (Marcgraviaceae) was developed, representing one of the first in vitro cultures for the family. This species was previously very difficult to cultivate from seed or cuttings.

METHODS: Methods included (1) the improvement of seed germination by axenic culture (2) development of regenerative cultures in vitro, then cultivation under greenhouse and finally field conditions and (3) creation of cell suspensions. Phytochemical analysis was undertaken by liquid chromatography coupled to mass spectrometry (HPLC-MS).

RESULTS: The percentage of seed germination was improved from 2\% to 59\% in axenic culture and the full development of the seedling with its apical shoot and root took twenty-four days. The best seedling development was obtained in Gamborg B5 culture medium. Most friable callus formation, (66.7\%) was obtained in the Murashige and Skoog medium supplemented with naphthalene acetic acid $\left(1 \mathrm{mg} \cdot \mathrm{L}^{-1}\right)$ and kinetin $\left(0.5 \mathrm{mg} \cdot \mathrm{L}^{-1}\right)$ from which viable cell cultures were developed. Analysis identified 4 main triterpenes with both in vitro plants and greenhouse grown plants derived from them. The triterpenes were betulinic acid, ursolic acid, alpha-amyrin and beta-amyrin. The betulinic acid found in greenhouse plants was comparable to wild plants. The cell suspension cultures had much lower levels of betulinic acid than plants and are not at present a viable source of this anxiolytic triterpene.

DISCUSSION: The improvement in seed germination of this recalcitrant tropical species was highly successful. The subsequent in vitro propagation and progression of plants through greenhouse and field conditions to provide mature plants with active principle concentrations comparable to wild plants was promising. Friable callus was achieved but phytochemical analysis showed that the level of betulinic acid in callus was much lower than that found in mature plant tissue.
\end{abstract}

CONCLUSION: The method provides healthy plants for cultivation of this new medicinal plant and consequently harvesting of wild plants is not required.

KEYWORDS: 2,4-D and kinetin; anxiolytic; betulinic acid; cell suspensions; in vitro culture

\section{Introduction}

The neotropical forests of Central America and the Caribbean region have been classified as a biodiversity hotspot for scientific study because of high levels of endemism and threats to conservation [1]. Beside the value of these forests to humans as ecosystems that capture rainwater, fix $\mathrm{CO}_{2}$ etc, they hold great potential for new biodiversity based products and applications beyond the destructive extraction of wood products or conversion of forests to agriculture. Many non-timber forestry products can be derived from them ranging from ornamental flowers, to natural products from plant secondary metabolism that can be developed as nutraceuticals, 
evidence based medicinal plants, insecticides, essential oils for flavorings etc. Our research group has been studying the potential of the neglected tropical family, Marcgraviaceae. It consists of 7 genera and 130 species in the neotropics and there are 7 genera and 26 species distributed in Central America and the Caribbean [2]. Among these, the species, Souroubea sympetala Gilg. was discovered by our group to reduce anxiety in behavioral tests in rodents using the elevated plus maze and other paradigms [3]. It is a woody vine with large roots, alternate simple leaves and racemic inflorescence with attractive red to orange flowers which have potential as an ornamental plant. Phytochemical studies conducted with this species led to the identification of anxiolytic active principles as the triterpenes, betulinic acid and alpha and beta amyrins [3]. Animal trials using standardized extracts showed that the anxiolytic activity was abolished by co-administration of a $\mathrm{GABA}_{\mathrm{A}}$ benzodiazapine antagonist, flumaziniel [4]. S. sympetala has recently been used in a formulation with another source of betulinic acid, Platanus occidentalis as an anxiolytic for companion animals. It was found to have a good safety profile in dogs and reduced their cortisol levels significantly in a thunderstorm model of noise aversion [4].

Responsible use of tropical biodiversity includes a plan for agriculture propagation and/or tissue culture production to conserve species and provide high quality pathogen free germplasm for local use. Unfortunately, agriculture production of $S$. sympetala in our trials was limited by the low germination of the recalcitrant tropical seeds. Typically, around $2-5 \%$ of seeds germinate, with a high rate of fungal infection. Our attempts at reproducing plants with cuttings had a very low success rate $(>7 \%)$. As an alternative, cell culture has never been attempted for this genus and possibly other Marcgraviaceae, which may be a biotechnological route to production of anxiolytic extracts.

The objectives of the present research were to establish (1) a method for in vitro germination of S. sympetala seeds, which are pathogen free (2) regenerative cultures for S. sympetala plants (3) development of cell suspension cultures as a possible in vitro production of bioactive metabolites. The phytochemical chemical composition of regenerated root, stem, leaf and cell suspension culture was also studied.

\section{Methods}

\section{Plant Material}

The plant material was collected at the "Cerro Tortuguero", Caño Palma, Limón, Costa Rica, at the geographic coordinates: $100^{\circ} 36^{\prime} 1.36^{\prime} \mathrm{N}$ and $83^{\circ} 31^{\prime}$ $56.91^{\prime \prime}$ W. The plant material was identified by Marco
Otarola Rojas and Pablo Sanchez Vindas at the Juvenal Valerio Rodriguez herbarium, UNA. A voucher specimen (\#131231) was deposited in the herbarium.

\section{In Vitro Seed Germination of Souroubea Sympetala}

This portion of the research was conducted at the Laboratory of Plant Tissue Culture, Institute of Research and Forestry Services (INISEFOR), National University.

Fruits without visible symptoms of contamination by fungi, bacteria or yeast, or mechanical or physical injury were selected. The fruits were surface disinfected as follows: they were brushed with soap (antibacterial Brand Bactex) and water. Subsequently, they were immersed in $70 \%$ ethanol for 1 minute and then dipped in 3.5\% (v/v) sodium hypochlorite in water for 20 minutes. Finally, three washes with sterile water were performed in a laminar flow chamber.

During the aseptic removal of the seeds from fruit, most of the fleshy tissue of the fruits was removed. Each seed was scarified by nicking the seedcoat with a sterile scalpel and cultured aseptically in a test tube with $10 \mathrm{ml}$ of solid Murashige and Skoog (MS) medium [5] pH 5.7 (MS basal medium with 3\% sucrose and solidified with $0.7 \%$ w/v agar, Sigma).

Each experimental unit consisted of a test tube with a scarified seed. Three replicates were performed per experimental block. Each block had 100 seeds distributed in a randomized design. These were placed in the growth chamber at a temperature of $25^{\circ} \mathrm{C}$ with a photoperiod of 16:8 L:D and $24.2 \mu \mathrm{mol} \mathrm{m} \mathrm{m}^{-2} \cdot \mathrm{s}^{-1}$ light intensity. The evaluation of germination was performed every 8 days for 48 days.

\section{Establishment of In Vitro Plant Culture}

Germinated plants were transferred to three different culture media for in vitro propagation of the species: MS medium with 100\% nitrate, Gamborg B5 with 100\% nitrate (B5 medium) and Cowen's MC Woody Plant Medium (WPM medium) with 100\% nitrate [9]. MS and B5 media were supplemented with 3\% sucrose and solidified with phytagel $0.27 \%$; the $\mathrm{pH}$ of the media was adjusted to 5.7 before sterilization $\left(21^{\circ} \mathrm{C}, 103 \mathrm{kPa}\right.$ pressure, $25 \mathrm{~min}$ ). In the case of WPM medium, 2\% sucrose was added and solidified with phytagel $0.27 \%$; the $\mathrm{pH}$ of the medium was adjusted to 5.5 before sterilization $\left(21^{\circ} \mathrm{C}, 103 \mathrm{kPa}\right.$ pressure, $\left.25 \mathrm{~min}\right)$. Each culture medium was distributed in a random fashion in the growth cabinet. Each experimental unit consisted of a glass bottle (baby food jar) containing $25 \mathrm{ml}$ of the respective culture medium. There were 20 replications per treatment. Each plant was initially $2 \mathrm{~cm}$ in size. The cultivated material was placed in the growth chamber at a 
temperature of $25^{\circ} \mathrm{C}$ with a photoperiod of 16:8 L:D and $24.2 \mu \mathrm{mol} \mathrm{m}{ }^{-2} \cdot \mathrm{s}^{-1}$ light intensity. Evaluation of development was performed every 15 days for three months. In each, length $(\mathrm{cm})$ was determined. Then the plants were transferred to a fresh culture medium of the same treatment. The experiment was conducted twice.

The effect of gibberellic acid (GA3) on the elongation of the explants was evaluated. The best culture medium determined by the establishment of Souroubea sympetala in vitro was used. All culture media were supplemented with $2 \%$ sucrose and solidified with phytagel $0.27 \%$; the $\mathrm{pH}$ of the media was adjusted to 5.5 before sterilization $\left(21^{\circ} \mathrm{C}, 103 \mathrm{kPa}, 25 \mathrm{~min}\right)$. Each culture medium was distributed in a random design of four treatments: $0.0 \mathrm{mg} \cdot \mathrm{L}^{-1}, 0.5 \mathrm{mg} \cdot \mathrm{L}^{-1} 1.0 \mathrm{mg} \cdot \mathrm{L}^{-1}$ and $1.5 \mathrm{mg} \cdot \mathrm{L}^{-1}$ of GA3. Each experimental unit (treatment) consisted of a baby food jar containing $25 \mathrm{ml}$ of the respective culture medium with 20 replications per treatment. The initial explant was an average length of $1.0 \mathrm{~cm}$. The cultivated material was placed in the growth chamber at a temperature of $25^{\circ} \mathrm{C}$ with a photoperiod of 16:8 L:D and $24.2 \mu \mathrm{mol} \mathrm{m} \mathrm{m}^{-2} \cdot \mathrm{s}^{-1}$. The evaluation was performed every 30 days for three months. For each explant, the number of shoots and shoot length $(\mathrm{cm})$ were evaluated. After each month of culture in laminar flow hood, each explant was transferred to fresh media.

\section{Greenhouse Acclimatization and Field Growth}

Twenty plantlets with a taproot were used with an average height of $2.0 \mathrm{~cm}$. In the greenhouse, in vitro plants were removed from the culture dish using the protocol established by Valverde et al. (2004) [7]. The plant length $(\mathrm{cm})$ and percentage survival was evaluated. The evaluation was performed every 15 days for 60 days. Subsequently, the plants were planted in a field trial in San Ramon de La Virgen de Sarapiqui, Costa Rica.

\section{Callus Induction In Vitro}

Root segments $(2 \mathrm{~cm})$ obtained from in vitro mother stocks established with optimal medium for the development of crop species were used. Subsequently, the root segments were cultured on MS medium described above, supplemented with ingredients (Table 1) adjusted to $\mathrm{pH}$ 5.8. The root segments were placed in contact with the culture medium.

For friable callus formation, the callus formed was sub-cultured every 30 days in the same culture medium used for induction. To multiply each callus, it was separated into small pieces. All explants were kept in the dark at $25 \pm 2^{\circ} \mathrm{C}$. Friable callus formation was evaluated
Table 1. Treatments used for callus induction in root segments of Souroubea sympetala.

\begin{tabular}{|c|c|}
\hline Treatment & Concentration of growth regulator $(\mu \mathrm{M})$ \\
\hline 1 & $2.22,4-D$ \\
\hline 2 & $4.52,4-D$ \\
\hline 3 & $6.72,4-D$ \\
\hline 4 & $9.02,4-D$ \\
\hline 5 & $11.32,4-D$ \\
\hline 6 & $13.52,4-D$ \\
\hline 7 & 2.0 Picloram \\
\hline 8 & 4.1 Picloram \\
\hline 9 & 6.2 Picloram \\
\hline 10 & 8.2 Picloram \\
\hline 11 & 10.3 Picloram \\
\hline 12 & 12.4 Picloram \\
\hline 13 & 4.6 KIN +18.0 2,4-D \\
\hline 14 & 4.6 KIN + $22.62,4-\mathrm{D}$ \\
\hline 15 & 4.6 KIN + 27.12,4-D \\
\hline 16 & 4.4 BAP + 13.5 2,4-D \\
\hline 17 & 4.4 BAP + 18.0 2,4-D \\
\hline 18 & 4.4 BAP + 22.65 2,4-D \\
\hline 19 & 4.4 BAP + $27.1462,4-D$ \\
\hline 20 & $2.3 \mathrm{KIN}+5.3 \mathrm{NAA}$ \\
\hline 21 & $2.3 \mathrm{KIN}+10.7 \mathrm{NAA}$ \\
\hline 22 & $2.3 \mathrm{KIN}+16.1 \mathrm{NAA}$ \\
\hline Control & 0 \\
\hline
\end{tabular}

every 15 days for 75 days, and the presence of some sort of contaminant (bacterium or fungus).

\section{In Vitro Establishment of Cell Suspensions}

Callus formed from root segments with high friability and a weight of $0.75 \mathrm{~g}$ were placed in $50 \mathrm{~mL}$ Erlenmeyer flasks with $10 \mathrm{~mL}$ of the best treatment determined in the above section (Table 1), but in liquid form. The bottles were sealed with cotton plugs and aluminum lids and kept in indirect light $\left(6.13 \mu \mathrm{mol} \mathrm{m} \mathrm{m}^{-2} \cdot \mathrm{s}^{-1}\right)$ under constant stirring at $100 \mathrm{rpm}$ at $25 \pm 2^{\circ} \mathrm{C}$ with 20 replicate. Fresh medium $(5 \mathrm{~mL})$ was replaced each month. Subculture using $5 \mathrm{~mL}$ of the suspension was transferred to a new vial with $5 \mathrm{~mL}$ culture medium to a total volume of $10 \mathrm{~mL}$.

\section{The Analysis of Concentration of Phytochemical Compounds in In Vitro Plants, Greenhouse Plants and Cell Suspensions of Souroubea Sympetala}

The in vitro plants and greenhouse plants were separated by plant part for phytochemical analysis. Dried roots, stem and leaves $(0.5 \mathrm{~g})$ were analyzed separately. 
Greenhouse plants were grown in sand in a humidity chamber with watering three times daily, with a run time of 2 minutes. In vitro plants analyzed were cultured on B5 medium with $2 \%(\mathrm{~m} / \mathrm{v})$ sucrose, $0.27 \%(\mathrm{~m} / \mathrm{v})$ phytagel and adjusted to $\mathrm{pH} 5,5$. The cultures were maintained at $25 \pm 2^{\circ} \mathrm{C}$, with a photoperiod of 12:12 L:D and a light intensity of $24.2 \mu \mathrm{mol} \mathrm{m}{ }^{-2} \cdot \mathrm{s}^{-1}$.

For cell suspension culture, $200 \mathrm{~mL}$ corresponding to 20 replicates were analyzed. Each cell suspension culture $(10 \mathrm{~mL})$ was grown in a $50 \mathrm{~mL}$ Erlenmeyer flask. To each Erlenmeyer in a laminar flow cabinet, were added $5 \mathrm{~mL}$ of cell suspension and $5 \mathrm{~mL}$ of $\mathrm{B} 5$ medium supplemented with $2 \%(\mathrm{w} / \mathrm{v})$ sucrose, $0.5 \mathrm{mg} \cdot \mathrm{L}^{-1}$ kinetin (KIN) and $1 \mathrm{mg} \cdot \mathrm{L}^{-1}$ napthalene acetic acid (NAA), adjusted to $\mathrm{pH} 5.5$, previously autoclaved for $20 \mathrm{~min}$ utes at $121^{\circ} \mathrm{C}$ and a pressure of $103 \mathrm{kPa}$. The cell cultures were sealed and kept in indirect light $(6.13 \mu \mathrm{mol}$ $\left.\mathrm{m}^{-2} \cdot \mathrm{s}^{-1}\right)$ at constant stirring at $100 \mathrm{rpm}$ at $25 \pm 2^{\circ} \mathrm{C}$. The suspension cells were harvested, fresh weight was determined, then frozen at $-20^{\circ} \mathrm{C}$, lyophilized and its dry weight determined.

The samples were transferred to the University of Ottawa for analysis using a validated method for triterpenes [4]. Briefly, they were extracted with $250 \mathrm{ml}$ of ethyl acetate for 2 hours in a Soxhlet extractor. The extracts were combined and dried by evaporation in a rotary evaporator at $45^{\circ} \mathrm{C}$ and re-dissolved in $20 \mathrm{ml}$ of methanol and placed in the sonicator for $2 \mathrm{~min}$ utes. The three extracts were placed in a volumetric flask and the total volume of the extract was adjusted to $50 \mathrm{ml}$. Subsequently, a $1 \mathrm{~mL}$ aliquot of each extract was taken and filtered through a PTFE membrane filter $(0.22 \mu \mathrm{m})$. Finally, the samples were analyzed by high pressure liquid chromatography coupled to tandem mass spectrometry (HPLC-MS-MS) QTRAP Sciex 3200 AB model.
For plantlets from greenhouse, the procedure was similar to the above, except that they were not lyophilized but oven dried at $60^{\circ} \mathrm{C}$ for 48 hours.

\section{Detection and Quantification of Compounds}

Detection of the compounds was carried out in negative ion mode Q1M1 (for betulinic acid and ursolic acid) and in positive ion mode of mode ( $\alpha, \beta$ amyrin lupeol and betulin). For quantification of compounds, standard curves were constructed, using a standard of the respective compound.

\section{Statistical Analysis}

The collected data were processed with the InfoStat/ Professional version 1.1 (National University of Cordoba, Spain) statistical program. Differences between the different treatments were determined analysis of variance followed by a post hoc Tukey's multiple range test $(\mathrm{p}<0.05)$. Unless stated otherwise values reported are means \pm standard error.

\section{Results and Discussion}

\section{Seed Germination of Souroubea Sympetala}

At the first day of sowing of surface sterilized seeds in sterile culture medium, seeds were white and three days later the seeds began to have a green hue. Emergence of the radicle was also evident at 3 days (Figure 1A).

Germination (Table 2) increased rapidly until 8 days (to $53 \%$ ) and maximum germination (58\%) occurred at 24 days. At day 48 (last day of culture) there was no difference in germination at 24 days (Table 2).

The disinfection treatment yielded plants $96 \%$ free of contamination after 48 days of culture. This is a remarkable improvement over unsterilized seeds sown directly in soil where germination was estimated at only $2-5 \%$.

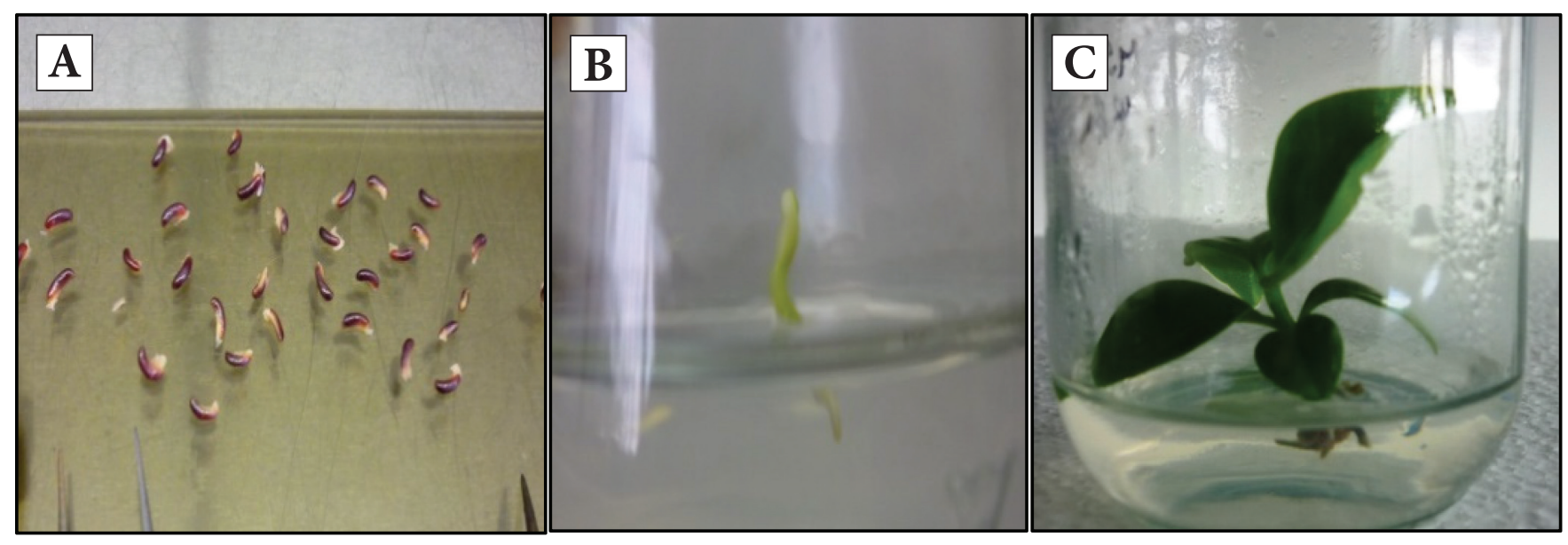

Figure 1. In vitro development of Souroubea sympetala in MS culture medium. (A) Seed germination (3 days). (B) Embryo development (8 days) and (C) Plantlet (48 days). 
Table 2. Mean \pm SE germination of Souroubea sympetala seeds in MS culture medium at different culture days.

\begin{tabular}{cc}
\hline Number of culture days & Germination (\%) \\
\hline 0 & 0 \\
8 & $53 \pm 0.15$ \\
16 & $56 \pm 0.0$ \\
24 & $58 \pm 0.0$ \\
\hline
\end{tabular}

Fungal growth observed in soil was eliminated in sterile culture. The removal of the seed coat of $S$. sympetala could also be a factor improving in vitro germination of the species. It has been reported previously that seed scarification of tropical species, either by exposing them briefly to concentrated sulfuric acid to soften the seed coat, or rubbing the seeds on a sheet of sandpaper, significantly improves germination $[8,9]$

\section{Establishment of In Vitro Plant Culture}

Shoots emerged by day 8 (Figure 1B) and formation of a fully developed healthy green plantlet was achieved by day 24 without fungal contamination (Figure 1C). Therefore, in accordance with Smith (2000) [6], the exposure time and concentration of disinfectant was mild enough that it did not cause damage to the seed or the growing plant.

Another aspect that favored the successful establishment of S. sympetala seedlings without pathogens, was the use of fruit, which was recommended by Kosky (1998) [10] to reduce contamination. S. sympetala fruiting occurs in the dry season (February to April in Central America) and there are fewer microorganisms present in the dry season than in the wet $[11,12]$.

Since S. sympetala is recalcitrant and seeds sown directly in soil germinated poorly and similarly, propagation from leaf and stem cuttings was very poor, the successful sterile seed culture method described here is a new method to ensure successful propagation.

\section{Growth of Plantlets in Different Nutrient Media}

Of the three nutrient growth media used (B5, MS or WPM), it was found that B5 was best for the growth of the plantlets in vitro. Significantly $(\mathrm{p}<0.05)$ greater growth over the 7 days was observed in plantlets grown in B5 culture medium as compared to MS and WPM medium (Figure 2). WPM and MS medium showed no significant differences. With B5 medium the best growth of plantlets was obtained, and they reached on average $>3.0 \mathrm{~cm}$ after 90 days of culture. Furthermore, the quality of the plants was always higher in this culture medium, the plants had a dark green color and were healthy and vigorous.

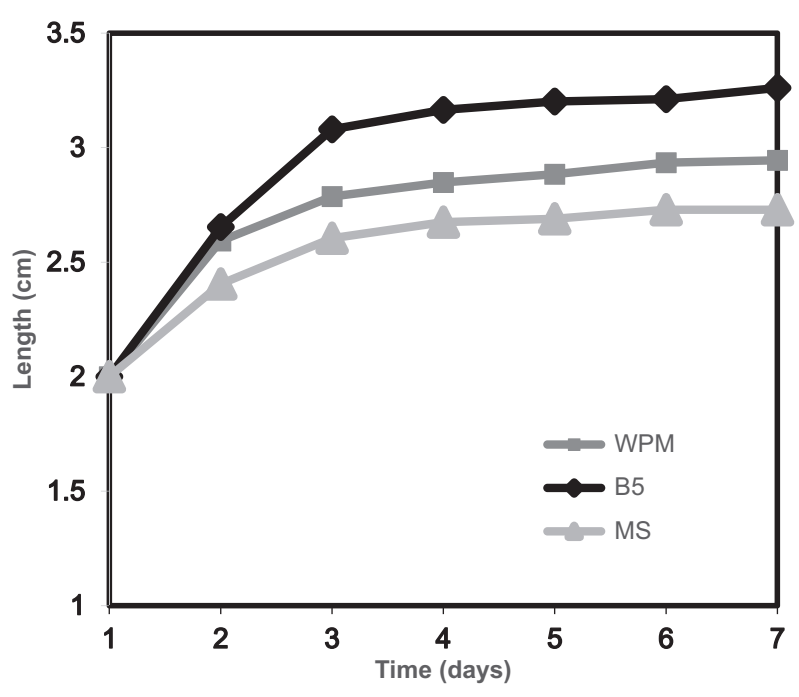

Figure 2. Growth response (mean length $(\mathrm{cm})$ ) of Souroubea sympetala plantlets in different culture media. Standard errors $<15 \%$ of mean are not shown.

While the MS medium is the most widely used worldwide for in vitro multiplication of species, B5 was better in our experiments. One of the major differences of B5 compared to MS is the concentration of the vitamin thiamine. B5 has over 100 times the concentration of thiamine in MS [13]. These results suggest that the presence of this specific vitamin is important for growth of S. sympetala, as noted by George (2008) [14] for several other species. Growth is reported to be directly related specifically to the biosynthesis of several amino acids enhanced by this vitamin. WPM also has 90 times less thiamine than B5, and was similarly not a good growth medium. Therefore, it is suggested that thiamine in large quantities favors development of $S$. sympetala under in vitro conditions. GA3 was evaluated with plantlets at different concentrations to promote growth and increase the elongation rate of the shoot [14]. The best result was obtained for elongation in culture medium supplemented with $0.5 \mathrm{mg} \cdot \mathrm{L}^{-1} \mathrm{GA} 3$, which showed a significant difference with the other treatments. However, it did not increase the mean growth of shoots by more than $1 \mathrm{~cm}$ even after 90 days of culture.

For in vitro propagation of this species, it was not essential to supplement the medium with growth regulators. In other species, the results of Pierik (1987) [15] and George (2008) [14] showed that GA3 successfully increased elongation in shoots during the multiplication stage. In our experiments, the average number of shoots per plant obtained with use of GA3 at different concentrations, showed no statistical difference between treatments on any of the days of culture.

In addition, the average number of shoots obtained ( 2 per plant or less), is low and the best results were obtained with sprouting treatment 4 and 2, with 0.5 and 

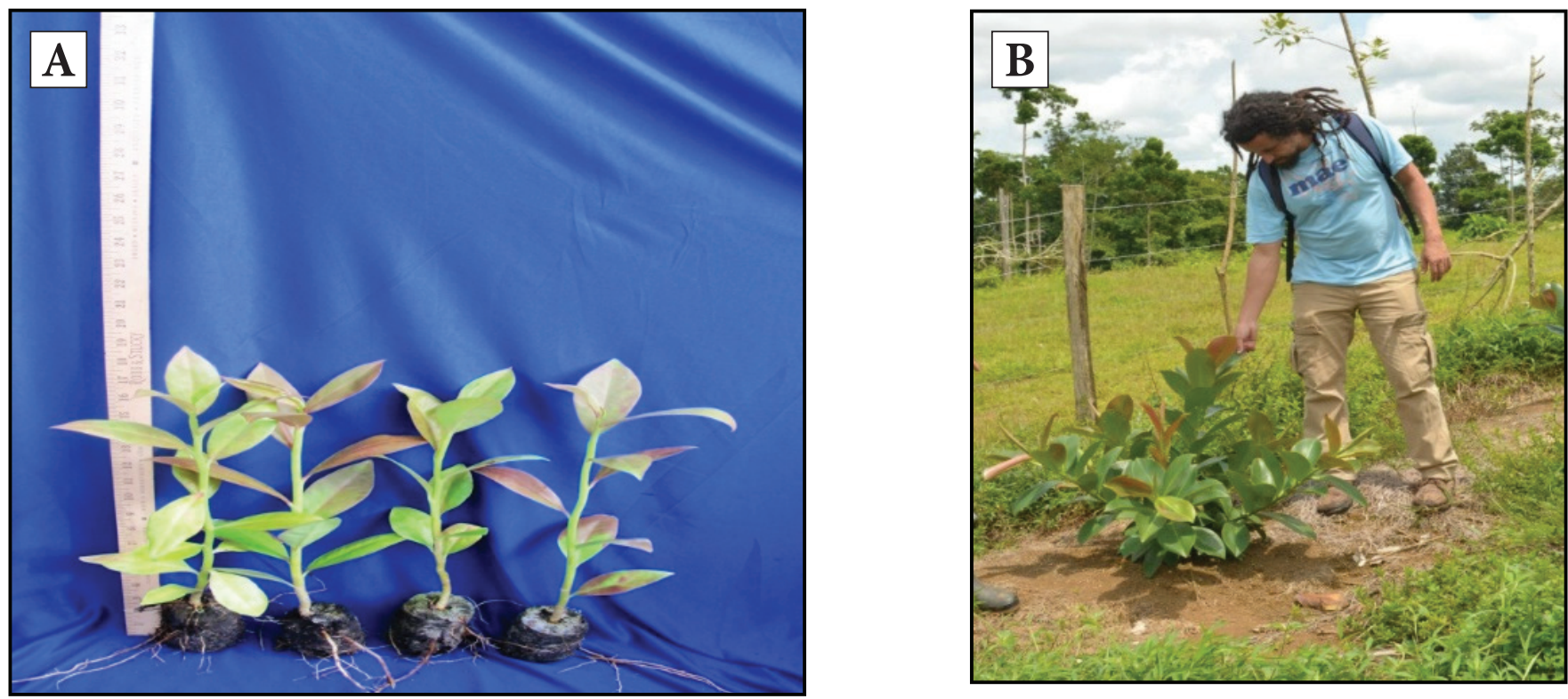

Figure 3. Souroubea sympetala plants (A) 150 days after greenhouse growth (B) 12 months after field planting.

$1.5 \mathrm{mg} \cdot \mathrm{L}^{-1} \mathrm{GA} 3$ respectively. Sprouting is not very different from that reported for other species which produce 3 new shoots per plant (Rout et al., 2000) [16].

\section{Ex Vitro Acclimatization in Greenhouse and Field Conditions}

Despite some challenges for in vitro propagation, $100 \%$ survival of the plantlets in the greenhouse was obtained. The plants reached an average size of $8 \mathrm{~cm}$, after 60 days of acclimatization and for each month of evaluation plants grew $1 \mathrm{~cm}$. The use of Jiffy pots provided mechanical support and let the roots take water and nutrients, so that and proper acclimatization and growth was achieved. After 150 days of greenhouse acclimatization, S. sympetala plants (Figure 3A) were planted in an experimental farm (Figure 3B).

For the next 12 months of growth plants showed excellent performance under field conditions. Plants showed an annual mortality rate in the field of $5 \%$. Therefore the method of acclimatization in the greenhouse was successful and led to obtain low mortality rates. Plants had a normal morphological and physiological development in the field.

\section{Callus Induction In Vitro}

For the development of cell suspension cultures as a possible in vitro production of bioactive metabolites, the explant used was a root segment. At 15 days after the start of growth, there was tissue deformation in treatments 2, 9, 10 and 20 (Table 3). Deformation started at the ends of the root segment, because at the site where the cut was made, the tissue responds to stress and an induced healing callus formed.
After 30 days of culture, 20 treatments showed increased amounts of deformation and protrusions. Decreased callus induction was seen in treatment \#2, 9 and 10. At 45 days of culture the protrusions formed in treatments \#2, 9,10 and 20 increased their biomass after subculture and formed calluses. In addition, treatment \#12 formed deformation early in the first days of culture.

Almost all treatments after 60 and 75 days of culture formed callus. However, the calluses formed had differences from each other in terms of color and friability. This coincides with observation by George (2008) [14], who described differences that occur in color, appearance, degree of compaction and morphogenetic response, depending on the type of explant and type of growth regulator used for induction.

The response rate to callus formation was not the same for the 22 treatments (Table 3). This is most likely due to the effect of exogenous growth regulators that were in the culture medium, stimulating cell metabolism, which went from a quiescent state to an active state of division. Furthermore, according to the literature, an auxin and cytokinin combination promotes the induction of friable calluses in many species as it did here in S. sympetala $[14,15]$. The best treatment was \#20 where a friable callus increased biomass with each subculture. It was used for the establishment of cell suspensions.

The rest of the treatments that formed calluses were more compact. The use of high concentrations of auxins like 2,4-D and picloram (treatments 1-12), were included with the aim of increasing the specific activity of enzymes that act on the dissolution of the middle lamella of the cell wall of the plant. 
Table 3. Mean \pm SE induction (\%) of callus response of Souroubea sympetala on different days of culture. Different letters in a row indicate significant differences in Tukey's multiple range test $(p<0.05)$.

\begin{tabular}{|c|c|c|c|c|c|c|}
\hline \multirow[b]{2}{*}{ Treatment } & \multicolumn{6}{|c|}{ Number of days of culture } \\
\hline & 0 & 15 & 30 & 45 & 60 & 75 \\
\hline 1 & 0 & $18.3 \pm 3.0 \mathrm{a}$ & $18.3 \pm 3.0 \mathrm{a}$ & $30.0 \pm 9.2 \mathrm{ab}$ & $48.3 \pm 12.3 \mathrm{ab}$ & $51.7 \pm 12.5 \mathrm{a}$ \\
\hline 2 & 0 & $45.1 \pm 11.6 b$ & $40.0 \pm 11.6 b$ & $58.9 \pm 12.4 b$ & $73.2 \pm 11.9 \mathrm{~b}$ & $73.2 \pm 11.8 c$ \\
\hline 3 & 0 & $6.45 \pm 1.67 \mathrm{a}$ & $3.33 \pm 2.27 a$ & $40 \pm 11.1 \mathrm{~b}$ & $35 \pm 12.4 a b$ & $53.3 \pm 13.3 b c$ \\
\hline 4 & 0 & $0 \pm 0 \mathrm{a}$ & $0 \pm 0 \mathrm{a}$ & $0 \pm 0 \mathrm{a}$ & $23.3 \pm 10.5 \mathrm{a}$ & $33.3 \pm 12.6 \mathrm{abc}$ \\
\hline 5 & 0 & $0 \pm 0 a$ & $1.67 \pm 1.67 \mathrm{a}$ & $3.33 \pm 2.27 \mathrm{a}$ & $6.67 \pm 5.16 a$ & $6.67 \pm 5.16 a$ \\
\hline 6 & 0 & $0 \pm 0 a$ & $1.67 \pm 1.67 \mathrm{a}$ & $3.33 \pm 2.27 \mathrm{a}$ & $10.0 \pm 6.8 \mathrm{a}$ & $15.0 \pm 9.0 \mathrm{ab}$ \\
\hline 7 & 0 & $0 \pm 0 \mathrm{a}$ & $0 \pm 0 \mathrm{a}$ & $0 \pm 0$ a & $0 \pm 0 \mathrm{a}$ & $0 \pm 0 \mathrm{a}$ \\
\hline 8 & 0 & $6.45 \pm 1.67 \mathrm{a}$ & $5.00 \pm 2.67 a$ & $15.0 \pm 9.1 \mathrm{ab}$ & $21.7 \pm 9.7 \mathrm{ab}$ & $28.3 \pm 11.7 \mathrm{ab}$ \\
\hline 9 & 0 & $26.5 \pm 6.8 \mathrm{ab}$ & $18.3 \pm 6.7 \mathrm{ab}$ & $33.3 \pm 10.5 \mathrm{ab}$ & $46.7 \pm 10.9 b c$ & $61.7 \pm 11.4 b c$ \\
\hline 10 & 0 & $38.0 \pm 6.8 b$ & $36.7 \pm 8.8 b$ & $85.0 \pm 8.0 c$ & $95.0 \pm 5.0 \mathrm{~d}$ & $95.0 \pm 5.0 \mathrm{c}$ \\
\hline 11 & 0 & $0 \pm 0 a$ & $1.67 \pm 1.67 \mathrm{a}$ & $1.67 \pm 1.67 \mathrm{a}$ & $11.7 \pm 8.0 \mathrm{ab}$ & $15.0 \pm 9.1 \mathrm{a}$ \\
\hline 12 & 0 & $0 \pm 0 a$ & $3.33 \pm 2.27 \mathrm{a}$ & $46.7 \pm 13.3 b$ & $60.0 \pm 13.1 \mathrm{~cd}$ & $60 \pm 13.1 b c$ \\
\hline 13 & 0 & $0 \pm a$ & $0 \pm 0 \mathrm{a}$ & $2.78 \pm 2.78 \mathrm{a}$ & $2.78 \pm 2.78 \mathrm{a}$ & $36.1 \pm 14.5 \mathrm{a}$ \\
\hline 14 & 0 & $0 \pm a$ & $0 \pm 0 \mathrm{a}$ & $0 \pm 0 \mathrm{a}$ & $0 \pm 0 \mathrm{a}$ & $18.3 \pm 7.1 \mathrm{a}$ \\
\hline 15 & 0 & $0 \pm a$ & $5.00 \pm 2.67 a$ & $5.00 \pm 2.67 a$ & $5.00 \pm 2.67 a$ & $18.3 \pm 7.1 \mathrm{a}$ \\
\hline 16 & 0 & $0 \pm a$ & $0 \pm 0 \mathrm{a}$ & $0 \pm 0 \mathrm{a}$ & $0 \pm 0 \mathrm{a}$ & $16.7 \pm 7.59 \mathrm{a}$ \\
\hline 17 & 0 & $0 \pm a$ & $3.33 \pm 2.27 \mathrm{a}$ & $3.33 \pm 2.27 a$ & $3.33 \pm 2.27 \mathrm{a}$ & $10.7 \pm 7.28 \mathrm{a}$ \\
\hline 18 & 0 & $0 \pm a$ & $0 \pm 0 \mathrm{a}$ & $0 \pm 0 \mathrm{a}$ & $0 \pm 0 \mathrm{a}$ & $13.3 \pm 4.8 \mathrm{a}$ \\
\hline 19 & 0 & $0 \pm a$ & $6.67 \pm 2.95 \mathrm{a}$ & $6.67 \pm 2.95 \mathrm{a}$ & $6.67 \pm 2.95 a$ & $11.7 \pm 5.38 \mathrm{a}$ \\
\hline 20 & 0 & $15.4 \pm 3.98 a$ & $16.7 \pm 7.18 \mathrm{a}$ & $30 \pm 9.19 a$ & $45.0 \pm 10.1 \mathrm{a}$ & $66.7 \pm 7.97 \mathrm{a}$ \\
\hline 21 & 0 & $0 \pm 0 a$ & $20 \pm 9.82 \mathrm{a}$ & $41.6 \pm 11.4 a$ & $51.7 \pm 12.3 a$ & $60 \pm 1.65 a$ \\
\hline 22 & 0 & $8.80 \pm 2.27 a$ & $3.33 \pm 2.27 \mathrm{a}$ & $25.0 \pm 9.1 \mathrm{a}$ & $41.7 \pm 11.4 \mathrm{a}$ & $53.3 \pm 12.7 a$ \\
\hline Control & 0 & $0 \pm 0 \mathrm{a}$ & $0 \pm 0 a$ & $0 \pm 0 \mathrm{a} 0$ & $0 \pm 0$ a0 & $0 \pm 0 \mathrm{a}$ \\
\hline
\end{tabular}

Table 4. Concentration ( $\mathrm{mg} / \mathrm{g}$ ) (mean $\pm \mathrm{SE}, \mathrm{n}=5$ ) of triterpenes in tissue or cell suspensions of Souroubea sympetala detected by HPLC-MS.

\begin{tabular}{|c|c|c|c|c|}
\hline Organ & Betulinic acid & Ursolic acid & a amyrin & $\beta$ amyrin \\
\hline Leaves of in vitro plantlets* & 0.082 & 0 & 0.219 & 0.476 \\
\hline Stem of in vitro plantlets* & 0.652 & 0 & 0.350 & 0 \\
\hline Leaves of greenhouse plants & $0.0148 \pm 0.003$ & $0.013 \pm 0.008$ & $3.06 \pm 0.39$ & $1.64 \pm 0.10$ \\
\hline Stem of greenhouse plants & $1.71 \pm 0.40$ & $0.0072 \pm 0.005$ & $0.103 \pm 0.011$ & $0.101 \pm 0.10$ \\
\hline Cellular suspension* & 0.020 & 0.08 & 0.170 & 3.65 \\
\hline
\end{tabular}

Note: $\mathrm{Nd}=$ not detected.

* = Samples bulked to obtain enough sample for analysis with 3-5 replications.

\section{In Vitro Establishment of Cell Suspension Culture}

Cell suspensions were established with friable callus formed from root segments of callus induction treatment \#20. Cell suspensions had a light brown coloration. After one year of subculture, $460 \mathrm{ml}$ of cell suspension was generated, which suggested that cell growth was very slow. Future changes in procedures may improve growth, such as increasing the amount of initial callus, increasing rotation speed to improve the disintegration of the cells, and modification of medium.

\section{The Concentration of Phytochemical Compounds In Vitro Plants, Greenhouse Plants and Cell Suspensions S. sympetala}

Phytochemical analysis (Table 4) was performed to determine the concentration of the triterpenes present in root, leaf and stem of plantlets generated by in vitro propagation, the greenhouse plants and established cell suspensions.

Betulinic acid was present in all organs analyzed in the in vitro plantlets, but the largest amount was detected 
in stems. Betulinic acid was highest in the root of the greenhouse plants. It is likely that in vitro plantlets produced less betulinic acid in all plant parts than mature plants because of their early growth stage as we have observed previously that larger concnetrations of triterpenes accumulate in older wild plants. The greenhouse grown plants had comparable amounts of triterpenes to previously analyzed wild grown plants at the same stage [17] suggesting that passage through the in vitro stage doesn't affect phytochemistry of more mature plants. This is similar to observations reported by Karuppusamy [18], for other species, that the plant cell, tissue or organ that is grown in vitro often has the ability to produce and accumulate the same phytochemicals as wild plants.

Otárola [19] reported that when wild plants of S. sympetala have more sunlight there is an increase in the production of betulinic acid compared to shade plants. Therefore, a change in the lighting conditions for growth could induce in vitro plants to produce greater amount of betulinic acid.

The cell suspension cultures did produce measurable amounts of betulinic acid, but the concentration was almost 2 orders of magnitude less that roots or leaves of mature plants. Clearly, at this stage of method development cell suspensions are not a good source of this main active compound. Rout et al. (2000) noted that the accumulation of secondary metabolites during in vitro culture depends on the composition of the culture medium, including type and amount of growth regulators, minerals and carbon sources as well as ambient conditions, temperature, light and gas composition during cultivation. A variety of physical and chemical conditions besides light could be changed to improve the in vitro production of betulinic acid in future work. In addition, elicitors should be studied in future work and could enhance the phytochemical yield substantially.

Ursolic acid was detected in very small quantities (Table 4) only in established plants in the greenhouse. Ursolic acid is a triterpene reported to have biological antimalarial and antimicrobial activity [20] but was not anxiolytic in our trials. The triterpenes, $\alpha$ and $\beta$ amyrin were found in much greater quantity in the organs of in vitro plants and established plants in the greenhouse. These compounds have some mild anxiolytic activity and may synergize betulinic acid [4].

\section{Conclusions}

This is the first report of methods to improve propagation of S. sympetala by in vitro methods from seed and was necessary because both wild seed germination and greenhouse propagation from leaf and stem cuttings was poor. The present protocol could be used to establish pathogen free plantations of the species for agriculture production. It is the first report of in vitro culture of $S$. sympetala and demonstrates that it can be easily grown as a cell culture. The methods may be transferable to other Marcgraviaceae, which appear to have received little or no study and are likely to pose similar challenges to propagation. The tissue culture protocol produced callus and cell suspension culture easily which may have future potential in research. In vitro propagation from stem and leaf material from greenhouse or field plants is the next step and will be studied in future work.

\section{List of Abbreviations}

NAA: napthylene acetic acid

BAP: 6-benzylaminopurine

B5 medium: Gamborg B5 with 100\% nitrate

GA-3: gibberellic acid

HPLC-MS-MS: high pressure liquid chromatography coupled to tandem mass spectrometry

$\mathrm{KIN}$ : kinetin

MS medium: Murashige and Skoog medium

WPM medium: Woody Plant medium

\section{Conflict of Interest}

Professors Durst, Arnason and Sanchez are members of Souroubea Botanicals Inc. which is involved in animal care products derived from Souroubea.

\section{Ethics Approval and/or Participant Consent}

No animals or human subjects were involved.

\section{Authors' Contributions}

ARV, AHG and JTA: made contributions to the design of the study, collected and analyzed data, drafted the manuscript, revised the manuscript critically, and gave final approval of the version to be published.

$\mathrm{RL}$, MOR: made substantial contributions to the design of the study, the collection of data as well as interpretation and analysis of the data, revised the manuscript critically, and gave final approval of the version to be published.

PBV, TD: contributed to study design and planning, assisted with the collection and analysis of data, and gave final approval of the version to be published.

\section{Funding}

Funding was provided by Souroubea Botanicals. 


\section{References}

[1] Myers N, Mittermeier RA, Mittermeier CG, Da Fonseca GA, Kent J. Biodiversity hotspots for conservation priorities. Nature. 2000 Feb;403(6772):853. doi:10.1038/35002501

[2] Zamora N. Flora digital de laselva. Organización para estudios Tropicales. http://sura.ots.ac.cr/local/florula3.2006

[3] Puniani E, Cayer C, Kent P, Mullally M, Sánchez-Vindas P, Álvarez LP, Cal V, Merali Z, Arnason JT, Durst T. Ethnopharmacology of Souroubea sympetala and Souroubea gilgii (Marcgraviaceae) and identification of betulinic acid as an anxiolytic principle. Phytochemistry. 2015 May 1;113:73-8. https://doi.org/10.1016/j.phytochem.2014.02.017

[4] Liu R, Ahmed F, Cayer C, Mullally M, Carballo AF, Rojas MO, Garcia M, Baker J, Masic A, Sanchez PE, Poveda L. New botanical anxiolytics for use in companion animals and humans. The AAPS Journal. 2017 Nov 1;19(6):1626-31. https://doi.org/10.1208/s12248-017-0144-y

[5] Murashige T, Skoog F. A revised medium for rapid growth and bio agsays with tohaoco tissue cultures. Physiologia Pantarum. 1962;15:473-97. https://doi.org/10.1111/ j.1399-3054.1962.tb08052.x

[6] Smith, R. Plant tissue culture techniques and experiments. Academic Press; 2000.

[7] Valverde-Cerdas L, Alvarado L, Hine A. Micropropagation of clones from controlled crosses of Gmelina arborea in Costa Rica. New forests. 2004 Sep 1;28(2-3):187-94. https://doi.org/10.1023/B:NEFO.0000040945.75019.38

[8] Araújo, Cardoso, V. Storage in cerrado soil and germination of Psychotria vellosiana (Rubiaceae) seeds. Brazilian Journal of Biology. 2006;66(2):709-717. http://dx.doi. org/10.1590/S1519-69842006000400015

[9] Salisbury FB, Ross CW. Fisologia de las plantas 3. Desarrollo de las plantas y fisiología ambiental. Paraninfo; 2006.

[10] Kosky, R. Cultivo de células y tejidos. p. 25-44. In Pérez, J. ed. Propagación y mejora genética de plantas por biotecnología. Instituto de Biotecnología de Plantas;1998.
[11] Burger W, Taylor CM. Flora Costaricensis: Family 202 Rubiaceae. Field Museum of Natural History; 1993. Fieldiana 33, 1-333.

[12] León, J. Los nombres comunes de las plantas en Costa Rica. Guayacán; 2000.

[13] Duchefa. Catalogue, 2010-12. Biochemicals, Plant Cell and Tissue Culture, Plant Molecular Biochemicals. Haarlem Netherlands,164 p.

[14] George EF, Hall MA, De Klerk GJ. Plant growth regulators I: introduction; auxins, their analogues and inhibitors. pp. 175-204. In Plant propagation by tissue culture Springer, 2008.

[15] Pierik, R. In vitro culture of higher plants. Dordrecht, NL, Ed Martinus Nijhoff; 1987.

[16] Rout GR, Samantaray S, Das P. In vitro manipulation and propagation of medicinal plants. Biotechnology advances. 2000 Apr 1;18(2):91-120. https://doi.org/10.1016/ S0734-9750(99)00026-9

[17] Mullally M, Kramp K, Saleem A, Rojas MO, Vindas PS, Garcia M, Alvarez LP, Durst T, Trudeau VL, Arnason JT. Characterization and quantification of triterpenes in the neotropical medicinal plant Souroubea sympetala (Marcgraviaceae) by HPLC-APCI-MS. Natural Product Communications. 2008 Nov;3(11): 1934578X0800301118. https://doi.org/10.1177/1934578X0800301118

[18] Karuppusamy S. A review on trends in production of secondary metabolites from higher plants by in vitro tissue, organ and cell cultures. Journal of Medicinal Plants Research. 2009 Dec 31;3(13):1222-39.

[19] Otárola Rojas, M. 2011. Caracterización del hábitat, requerimientos biológicos y nutricionales de Souroubea sympetala Gilg. Como un aporte al proceso de domesticación en los canales de Tortuguero, Limón, Costa Rica. Tesis Mag. Sc. Heredia, CR.UNA.57p.

[20] Innocente A, Silva G, Cruz L, Moraes M, Nakabashi M, Sonnet P, Gosmann G, Garcia C, Gnoatto S. Synthesis and antiplasmodial activity of betulinic acid and ursolic acid analogues. Molecules. 2012;17(10):12003-14. https://doi.org/10.3390/molecules171012003 


\section{Article Information}

Managing Editor: Roy M. Golsteyn

Peer Reviewers: Gyana Ranjan Rout, Roy M. Golsteyn

Article Dates: Received Nov 11 19; Accepted Jan 19 20; Published Feb 1820

\section{Citation}

Please cite this article as follows:

Vargas AR, Gómez AH, Liu R, Otarola-Rojas M, Vindas PS, Durst T, Arnason JT. In Vitro Culture of the Anxiolytic Plant, Souroubea Sympetala. Journal of Natural Health Product Research. 2020 Feb 18: 2(1). https://jnhpresearch.com/ index.php/jnhpr/article/view/7

DOI Link: https://doi.org/10.33211/jnhpr.7

\section{Copyright}

(c) Alejandra Rojas Vargas, Ana Hine Gómez, Rui Liu, Marco Otarola-Rojas, Pablo Sanchez Vindas, Tony Durst, John T. Arnason. (2020). Published first in the Journal of Natural Health Product Research. This is an open access article distributed under the terms of the Creative Commons Attribution License (https://creativecommons.org/ licenses/by/4.0/), which permits unrestricted use, distribution, and reproduction in any medium, provided the original work, first published in the Journal of Natural Health Product Research, an NHP Publications journal, is properly cited. The complete bibliographic information, a link to the original publication on https://www.jnhpresearch. com, as well as this copyright and license information must be included.

Journal of Natural Health Product Research NHTPRTRTIMATIONS

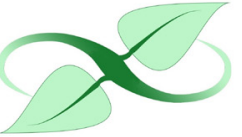

Canadà

Does the safety, efficacy, and quality of natural health products matter to YOU? Submit your research article to the Journal of Natural Health Product Research!

Pre-submission inquiries? Send us an email at editorial.office@jnhpresearch.com Facebook, Twitter and LinkedIn: @NHPPublications 